\title{
Management of Prevalent Diseases of Cucumber (Cucumis sativus) through Integrated Approach
}

\author{
A. T. Daunde* , R. D. Baghele and V.S. Khandare \\ All India Coordinated Research Project (Vegetable Crops), Vasantrao Naik Marathwada \\ Krishi Vidyapeeth, Parbhani (Maharashtra), India \\ *Corresponding author
}

\begin{tabular}{l} 
K e y w o r d s \\
$\begin{array}{l}\text { Cucumber, Downy } \\
\text { mildew, Damping- } \\
\text { off, Fosetyl-Al, } \\
\text { Trifloxystrobin, } \\
\text { mancozeb, Mulch. }\end{array}$ \\
\hline Article Info \\
$\begin{array}{l}\text { Accepted: } \\
\text { 22 June } 2020 \\
\text { Available Online: } \\
\text { 10 July } 2020\end{array}$ \\
\hline
\end{tabular}

\section{A B S T R A C T}

A wide range of pathogens (fungi, bacteria, and viruses) affect the productivity of cucumber crop, which renders its production uneconomical. Therefore, an integrated approach was developed for the management of prevalent diseases of cucumber like damping-off and downy mildew using strategies such as growing border crop, use of reflective mulches, soil application and spray of fungicides and insecticides. The results of the experiments showed that treatment comprising raising of two rows of maize as border crop in the main field 15 days before cucumber seed sowing along with sliver agrimulch sheet, seed treatment with Carbendazim12\% + Mancozeb 63\% WP @3g/kg and drenching of Captan70\% + Hexaconazole 5\% WP @ $0.1 \%$ 15days after germination followed by sequential spraying of Tebuconazole 50\% + Trifloxystrobin 25\% WP @ 1g/L, Imidacloprid 17.8SL @ 7.5ml/15L + Neemoil $0.2 \%$, Fosetyl-Al @ $0.1 \%$, Tebuconazole 50\% + Trifloxystrobin 25\% @ 1g/L, Imidacloprid 17.8SL @ 7.5ml/15L + Neemoil0.2\% and Fosetyl-Al @ $0.1 \%$ at 10 days interval till fruit formation was found significantly superior over all other treatment in terms of per cent incidence of dampingoff $(2.67 \%)$, downy mildew PDI (6.51) and fruit yield (126.80 q/ha) with better costbenefit ratio (1:1.71). This integrated approach is safe and ecologically sound and seems to be a healthy tactic for disease management.

\section{Introduction}

Cucumber (Cucumis sativus) is a widely cultivated plant in the gourd family, Cucurbitaceae. It is one of the most important cucurbitaceous crops cultivated throughout the world and in India due to its anti-oxidant and anti-inflammatory properties. Cucumber is commonly attacked by a wide range of diseases. Among those reported as causing substantial losses are powdery mildew, downy mildew, anthracnose, fusarium wilt, soil borne diseases and viral diseases such as mosaic, bud necrosis, leaf curl and leaf distortion virus.

Cucumber is more susceptible to downy mildew than other cucurbits (Ojiambo et al., 2010). Downy mildew of cucumber caused by the oomycetes Pseudoperonospora cubensis (Berk \& Curt.) Rostov is one of the most economically important and widespread plant 
pathogens in India and all over the world (Paltiand Cohen, 1980; Lehmann, 1991; Tsai et al., 1992; Lebedaand Cohen, 2011). Downy mildew of cucumber causes serious losses under favourable environmental conditions. In many regions with high humidity, the disease is the main limiting factor for cucumber production (Shetty and Wehner, 1997). Characteristic symptoms are angular, chlorotic lesions on the foliage. These lesions appear angular because they are bound by leaf veins. During humid conditions, the underside of the leaf reveals grey-brown to purplishblack 'down'. Eventually, leaves turn necrotic and curl upwards (Miriam et al., 2004; Chand et al., 2014).

Powdery mildew of cucumber is caused by the fungi Erysiphe cichoracearum DC and Sphaerotheca fuliginea (Schlecht. ex Fr.) Poll. Typical symptoms include white powdery growth on the upper surfaces of leaves and the stems of infected plants. Infected areas are often stunted and distorted and may drop prematurely from the plant. Fruits are usually not directly affected, but their size and growth may be stunted (Singhand Sahore, 2002; Morsy et al., 2009; Chand et al., 2014).

Several fungi or fungus-like microorganisms including Pythium sp., Fusarium sp., and Rhizoctonia sp., which live in soil and attack seedlings of cucumber. Seedlings are attacked before or after emergence, resulting in gaps and uneven stands. Young plants suddenly wilt and topple over. Water-soaked lesions are apparent on stems at the soil line for only a short time before the seedling dies. Chemical seed treatments still represent a major practice in agriculture to manage damping-off diseases (Babadoost and Islam, 2003; Dorrance et al., 2009; Lamichhane et al., 2017).

Several common viruses can affect cucumber, including Cucumber mosaic virus, Pumpkin mosaic virus and Watermelon mosaic virus. Infected plants may be stunted or have leaves that are mottled, crinkled, or a light green colour. Fruits may be irregular in shape, mottled or warty. Various insects transmit these viruses (Zitikaite, 2002; Chand et al., 2014).

Many plant pathogens survive in the soil and can survive during off season in soil debris. Mulch such as polythene mulch will help prevent both soils from splashing onto plants and fruit from touching the bare ground. Cucumber benefits from a mulch layer to help prevent diseases such as damping-off and downy mildew (Reuveni and Raviv, 1997).

There is a great need to carry out farmer level research pointing to develop a holistic disease management approach to manage the major diseases of cucumber. The present studies were therefore undertaken to develop effective and eco-friendly management practices such as growing border crop, use of polythene mulch, soil application as well as spray of fungicides and insecticides against prevalent diseases of cucumber.

\section{Materials and Methods}

The experiment was conducted at All India Coordinated Research Project (Vegetable Crops), Vasantrao Naik Marathwada Krishi Vidyapeeth, Parbhani, Maharashtra, India during the year 2017-18 in Kharif seasons using cucumber cv. Pune Khira for the management of prevalent diseases of cucumber. The soil of the experimental field was black cotton soil. The experiment was laid out in a randomized block design with three replications consisting of seven treatment combinations as shown below. Seeds were sown in the plots of $5 \times 2.5 \mathrm{~m}$ in size following pit sowing with a distance of 100x50 cm spacing. All recommended agronomic cultural practices were followed. 
The per cent disease incidence of damping-off was calculated using following formula.

Disease incidence $(\%)=\frac{\text { Number of diseased plants }}{\text { Total number of plants observed }} \times 100$

The downy mildew disease was quantified using disease grading 0-9 scale (Yangn et al., 2007) where, $0=$ Healthy Leaf, $1=1 \%-5 \%$, $3=6 \%-10 \%, 5=11 \%-25 \%, 7=26 \%-55 \%$, and $9=56 \%-100 \%$ of infected leaf. The percent disease index (PDI) was calculated as given below (Wheeler, 1969).

$\mathrm{PDI}=\frac{\text { Sum of all numerical ratings }}{\text { Total No of samples } \mathrm{x} \text { Maximum rating scale }} \times 100$

For this purpose, five plants were selected randomly from each plot and observations were taken from downy mildew infected leaves and statistically analysed. Plot wise cucumber fruit yield (recorded at each picking) were cumulated and converted into quintal/hectare and statistically analysed.

\section{Results and Discussion}

\section{Reduction in disease incidence}

Data presented in Table 1 revealed that significantly lowest damping-off incidence was recorded in treatment T5 (raising of two rows of maize as border crop in the main field 15 days before cucumber seed sowing along with sliver agrimulch sheet; seed treatment with Carbendazim 12\% + Mancozeb $63 \%$ WP @ 3g/kg and drenching of Captan 70\% + Hexaconazole 5\% WP @ $0.1 \% 15$ days after germination followed by sequential spraying of Tebuconazole 50\% + Trifloxystrobin $25 \%$ WP @ 1g/l, Imidacloprid 17.8SL @ 7.5ml/15L + Neemoil 0.2 \%, Fosetyl-Al@0.1 $\%$, Tebuconazole $50 \%$ + Trifloxystrobin $25 \%$ @ 1g/1, Imidacloprid17.8SL @7.5ml/15L+ Neemoil $0.2 \%$ and Fosetyl-Al @ $0.1 \%$ ) $(2.67 \%)$ followed by treatment T4 $(7.43 \%)$.
This was followed by treatment T3 $(12.33 \%)$ and T6 $(12.41 \%)$ were at par with each other. Treatment T1 $(17.31 \%)$ and T2 (17.90\%) were also at par with each other. However, the highest incidence of damping-off (22.01 $\%)$ was recorded in control.

Significantly lowest PDI of downy mildew was recorded in treatment T5 (raising of two rows of maize as border crop in the main field 15 days before cucumber seed sowing along with sliver agrimulch sheet; seed treatment with Carbendazim12\% + Mancozeb 63\% WP @ $3 \mathrm{~g} / \mathrm{kg}$ and drenching of Captan $70 \%+$ Hexaconazole5\% WP@0.1 \% 15 days after germination followed by sequential spraying of Tebuconazole 50\% + Trifloxystrobin $25 \%$ WP @ 1g/l, Imidacloprid 17.8SL @7.5ml/15L + Neemoil $0.2 \%$, Fosetyl-Al @ $0.1 \%$, Tebuconazole 50\% + Trifloxystrobin $25 \% @ 1 \mathrm{~g} / \mathrm{l}, \quad$ Imidacloprid 17.8SL @ 7.5ml/15L + Neemoil $0.2 \%$ and Fosetyl-Al (a $0.1 \%$ ) (6.51) followed by treatment T4 (13.11) and T3 (16.91) which were at par with each other. However, the highest PDI of downy mildew (36.00) was recorded in control.

\section{Yield and economics}

Data presented in Table 1 revealed that among all the treatments T5 (raising of two rows of maize as border crop in the main field 15 days before cucumber seed sowing along with sliver agrimulch sheet; seed treatment with Carbendazim 12\% + Mancozeb 63\% WP @ $3 \mathrm{~g} / \mathrm{kg}$ and drenching of Captan $70 \%+$ Hexaconazole 5\% WP @ $0.1 \% 15$ days after germination followed by sequential spraying of Tebuconazole 50\% + Trifloxystrobin 25\% WP @ 1g/l, Imidacloprid 17.8SL @ 7.5ml/15L + Neemoil 0.2\%, Fosetyl-Al @ $0.1 \%$, Tebuconazole 50\% + Trifloxystrobin 25\%@1g/l, Imidacloprid 17.8SL @ 7.5ml/15L + Neemoil 0.2\% and Fosetyl-Al @ $0.1 \%$ ) recorded the highest fruit yield of 
$126.80 \mathrm{q} / \mathrm{ha}$ which was statistically significant overall other treatments. This was followed by T4 (105.52 q/ha) and T3 (104.80 q/ha) whereas Control recorded the lowest fruit yield (54.80 q/ha).

The data presented in Table 2 showed that the highest cost-benefit ratio (1:1.71) was achieved with the treatment T5 (raising of two rows of maize as border crop in the main field 15 days before cucumber seed sowing along with sliver agrimulch sheet; seed treatment with Carbendazim 12\% + Mancozeb 63\% WP
@ 3g/kg and drenching of Captan70\% + Hexaconazole 5\% WP @ 0.1\% 15 days after germination followed by sequential spraying of Tebuconazole $50 \%$ + Trifloxystrobin 25\% WP @ 1g/l, Imidacloprid 17.8SL @ $7.5 \mathrm{ml} / 15 \mathrm{~L}+$ Neemoil $0.2 \%$, Fosetyl-Al @ $0.1 \%$, Tebuconazole $50 \%+$ Trifloxystrobin 25\%@1g/l, Imidacloprid 17.8SL@ $7.5 \mathrm{ml} / 15 \mathrm{~L}+$ Neemoil $0.2 \%$ and Fosetyl-Al @ $0.1 \%)$. This was followed by treatment T3 (1:1.63), T4 (1:1.47), T1 (1:1.40), T2 (1:1.36) and T6 (1: 1.34).

\section{Details of various treatments used for the integrated management of diseases}

\section{Details of treatment}

T0 Common to all treatments:Growingof tworows ofmaize as bordercrops anduseofagrisilvermulch sheet.

T1 Seed treatment with Seed Pro @ $25 \mathrm{~g} / \mathrm{kg}$ and soil drenching of Seed Pro @ 5\% at $1^{\text {st }}$ true leaf stage after germination followed by 5 spray of Seed Pro (1\%) at 10 day interval in rotation with Neem oil $(0.2 \%)$ alternatively after 15 days after drenching.

T2 SeedtreatmentwithCarbendazim12\%+ Mancozeb63\% @3g/kganddrenching ofCaptan70 \% +

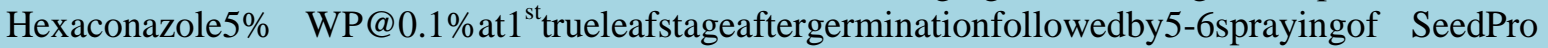
$(1 \%)$ at 10day intervalin rotationwithNeem oil $(0.2 \%)$ alternativelyafter15daysafter drenching.

T3 T0 + Seed treatmentwith Seed Pro @25 g/kgandsoildrenchingofSeed Pro @5\% 1sttrue leafstage aftergerminationfollowed by spraying of Captan70\%+ Hexaconazole5\% WP@0.1\%followedby spraying of ( Imidacloprid17.8SL@7.5ml/15L +Neemoil0.2\%) followed by Fosetyl-Al@0.1\% followedbyCaptan70 \% + Hexaconazole5\% WP@0.1\%followedbysprayingofImidacloprid17.8 SL @7.5 ml/15 L + Neemoil0.2\% followed byFosetyl-Al@0.1\%at10 daysinterval.

T4 Seed treatment with Seed Pro @ $25 \mathrm{~g} / \mathrm{kg}$ and soil drenching of Seed Pro @ 5\% at 1sttrue leaf stage after germination followed by spray of (Imidacloprid 17.8 SL @ $7.5 \mathrm{ml} / 15 \mathrm{~L}+$ Neem oil $0.2 \%$ ) followed by spray ofTebuconazole 50\% + Trifloxystrobin 25\% @ 1g/l followed by Fosetyl-Al @ $0.1 \%$, followed by spray of Tebuconazole 50\% + Trifloxystrobin 25\% @ 1 $\mathrm{g} / \mathrm{l}$ followed by spray of (Imidacloprid 17.8 SL@ 7.5 ml/15 L + Neem oil 0.2\%) followed by Fosetyl-Al @ 0.1\%at 10 daysinterval.

T5 Seed treatment with Carbendazim 12\% + Mancozeb 63\% @ 3 g/kgand drenching ofCaptan $70 \%$ + Hexaconazole 5\% WP @ 0.1\% 15 days after germination followed by spraying ofTebuconazole 50\% + Trifloxystrobin 25\% @ 1g/l + spray with (Imidacloprid 17.8 SL @ 7.5 ml/15 L + Neem oil $0.2 \%$ ) followed by Fosetyl-Al @ $0.1 \%$ followed by spraying of Tebuconazole $50 \%+$ Trifloxystrobin 25\% @ 1g/l + spray with (Imidacloprid 17.8 SL @ 7.5 ml/15 L +Neem oil 0.2\%) followed by Fosetyl-Al @ 0.1\% at 10 days interval.

T6 Seed treatment with Carbendazim 12\% + Mancozeb 63\% @ 3 g/kgand drenching ofCaptan $70 \%+$ Hexaconazole 5\% WP @ 0.1\% 15 days after germination followed by spray with (Imidacloprid 17.8 SL @ $7.5 \mathrm{ml} / 15 \mathrm{~L}+\mathrm{Neem}$ oil $0.2 \%) \%$ ) followed by spraying of Captan $70 \%+$ Hexaconazole $5 \%$ WP @ 0.1\%followed by Fosetyl- Al@0.1\%followed by spraying of Captan $70 \%+$ Hexaconazole 5\% WP @ 0.1\%+ spray with (Imidacloprid 17.8 SL @ 7.5 ml/15 L +Neem oil 0.2\%) \%) followed by Fosetyl- $\mathrm{Al} @ 0.1 \%$ at 30 days after drenching

T7 Control 
Table.1 Effect of integrated management treatment on the incidence of diseases and fruit yield (q/ha)

\begin{tabular}{|c|c|c|c|}
\hline \multirow[t]{2}{*}{ Treatments } & \multicolumn{2}{|c|}{ Incidence of diseases } & \multirow{2}{*}{$\begin{array}{l}\text { Yield } \\
\text { (q/ha) }\end{array}$} \\
\hline & Damping-off (\%) & Downy mildew (PDI) & \\
\hline T1 & $\begin{array}{c}17.31 \\
(24.57)^{*}\end{array}$ & $\begin{array}{c}27.30 \\
(31.48)\end{array}$ & 82.56 \\
\hline $\mathbf{T 2}$ & $\begin{array}{c}17.90 \\
(25.01)\end{array}$ & $\begin{array}{c}28.03 \\
(31.94)\end{array}$ & 81.20 \\
\hline T3 & $\begin{array}{c}12.33 \\
(20.56)\end{array}$ & $\begin{array}{c}16.91 \\
(24.25)\end{array}$ & 104.80 \\
\hline T4 & $\begin{array}{c}7.43 \\
(15.80)\end{array}$ & $\begin{array}{c}13.11 \\
(21.19)\end{array}$ & 105.52 \\
\hline T5 & $\begin{array}{c}2.67 \\
(9.11)\end{array}$ & $\begin{array}{c}6.51 \\
(14.61)\end{array}$ & 126.80 \\
\hline T6 & $\begin{array}{c}12.41 \\
(20.60)\end{array}$ & $\begin{array}{c}20.64 \\
(27.02)\end{array}$ & 83.76 \\
\hline T7 & $\begin{array}{c}22.01 \\
(27.97)\end{array}$ & $\begin{array}{c}36.00 \\
(36.84)\end{array}$ & 54.80 \\
\hline $\mathrm{SEm} \pm$ & 0.93 & 1.22 & 5.28 \\
\hline CD at $5 \%$ & 2.86 & 3.81 & 16.48 \\
\hline * Figures in p & thesis are ar & r transformations & \\
\hline
\end{tabular}

Table.2 Cost-benefit ratio as affected by integrated management treatments

\begin{tabular}{|c|r|r|r|r|r|c|}
\hline Treatments & $\begin{array}{c}\text { Total cost of } \\
\text { treatment } \\
\text { (Rs./ha) }\end{array}$ & $\begin{array}{c}\text { Yield } \\
\text { (q/ha) }\end{array}$ & $\begin{array}{c}\text { Cost of } \\
\text { production } \\
\text { (Rs/ha) }\end{array}$ & $\begin{array}{c}\text { Gross } \\
\text { Income } \\
\text { Rs/ha) }\end{array}$ & $\begin{array}{c}\text { Net profit } \\
\text { (Rs./ha) }\end{array}$ & $\begin{array}{c}\text { Cost } \\
\text { Benefit } \\
\text { Ratio }\end{array}$ \\
\hline T1 & 3493 & 82.56 & 59351 & 83200 & 23849 & $1: 1.40$ \\
\hline T2 & 4447 & 81.20 & 60215 & 81910 & 21695 & $1: 1.36$ \\
\hline T3 & 7053 & 104.80 & 64451 & 105210 & 40759 & $1: 1.63$ \\
\hline T4 & 14916 & 105.52 & 72404 & 106490 & 34086 & $1: 1.47$ \\
\hline T5 & 15879 & 126.80 & 74853 & 127720 & 52867 & $1: 1.71$ \\
\hline T6 & 7732 & 83.76 & 63722 & 85090 & 21368 & $1: 1.34$ \\
\hline T7 & - & 54.80 & 54370 & 58080 & 3710 & $1: 1.07$ \\
\hline
\end{tabular}

The present study is confirmatory with the result of (Kumar et al., 2018; Bagri et al., 2019) who reported that cucumber seed treatment with Carbendazim 12\% + Mancozeb 63\%@3 g/kg and drenching of Captan $70 \%$ + Hexaconazole 5\% WP @ $0.1 \% 15$ days after germination followed by spraying of Tebuconazole $50 \%+$ Trifloxystrobin 25\%@1g/l + spray with
Imidacloprid 17.8 SL @ 7.5 ml/15 L + Neem oil $0.2 \%$ followed by Fosetyl-Al @ 0.1\% followed by spraying of Tebuconazole $50 \%+$ Trifloxystrobin 25\%@1g/1 + spray with Imidacloprid 17.8 SL@ 7.5 ml/15 L + Neem oil $0.2 \%$ followed by Fosetyl-Al @ 0.1\% was effective against diseases of cucumber. Neem oil derived from Azadirachta indica controls downy mildew disease of cucurbits (Meister, 
1999; Utobo et. al., 2015). Many workers also reported that above fungicide were effective against downy mildew of cucumber (Kagadi et al., 2002; Gupta and Thind, 2006; Chaudhry et al., 2009; Ojiambo et al., 2010; Ghosh et al., 2014; Shankar et al., 2014; Ihsan et al., 2015; Lebeda et al., 2019).

In conclusion it may be concluded that, raising of two rows of maize as border crop in the main field 15 days before cucumber seed sowing along with sliver agrimulch sheet, seed treatment with Carbendazim $12 \%+$ Mancozeb 63\% WP @ 3g/kg and drenching of Captan 70\% + Hexaconazole 5\% WP @ $0.1 \% 15$ days after germination followed by sequential spraying of Tebuconazole $50 \%+$ Trifloxystrobin 25\% WP @ 1g/L, Imidacloprid 17.8SL @ 7.5ml/15L+ Neemoil0.2 \%, Fosetyl-Al @ $0.1 \%$, Tebuconazole 50\% + Trifloxystrobin25\% @ 1g/L, Imidacloprid 17.8SL @ 7.5ml/15L + Neemoil $0.2 \%$ and Fosetyl-Al @ $0.1 \%$ at10 days interval till fruit formation effectively manage damping-off and downy mildew of cucumber.

\section{References}

Babadoost, M. and Islam, S. Z. (2003). Fungicide seed treatment effects on seedlingdamping-off of pumpkin caused by Phytophthora capsici. PlantDis. 87:63-68.

Bagri, R. K., Singh, J., Goyal, S. K., Chawla, N. and Kumari, M. (2019). Integrated disease management of downy mildew in bottle gourd (Lagenaria siceraria (Mol.) Stand). J. Entomol. Zool. Stud., 7(4): 315-317.

Chand, G., Kumar S., Kureel, R. S. and Singh, D. (2014). Diseases of cucurbits, In: Diseases of vegetable crops: Diagnosis and management (Eds Singh, D., Chowdappa, P and Sharma, P.) Today \& Tomorrows's Printers and Publishers, New Delhi. p 185-242.
Chaudhry, S. U., Iqbal, J. and Mustafa, A. (2009). Efficacy of different fungicides for the control of downy mildew of cucumber.J. Anim. Plant Sci., 19(4):202204.

Dorrance, A. E., Robertson, A. E. and Cianzo, S. (2009). Integrated management strategies for Phytophthora sojae combining host resistance and seed treatments. Plant Dis., 93:875-882.

Ghosh, D., Bhattacharya, I., Dutta, S., Saha, A. and Majumdar, D. (2014). Management of cucumber downy mildew with fungicides. Indian J. Plant Protec., 42(4): 406-411.

Gupta, S. K. and Thind, T. S. (2006). Disease problems in vegetable production. Scientific Publishers (India), post Box No.91, Jodhpur. p 576.

Ihsan, J., Mohsan, Ali, M. Q. and Mohyudin, G. (2013).Evaluation of different fungicides for the management of downy mildew (Pseudoperonospora cubensis) of muskmelon. Pak. J. Phytopathol., 25 (02): 123-126.

Kagadi, S. R., Deadman, M. L., Pawar, D. R., and Gadre, U. A. (2002). Effect of fungicide control of downy mildew (Pseudoperonospora cubensis) on yield and disease management of ridge ground (Luffa acutangula).Plant Pathol. J., 18(3): 147-151.

Kumar, V., Kerketta, A., Sahu, A., Teta, A.and Khare. C. P. (2018). Management of prevalent diseases of bitter gourd (Momordica charantia L.). J. Pharmacogn. Phytochem., SP1: 26-35.

Lamichhane, J.R., Dürr, C. and Schwanck, A.A. (2017). Integrated management of damping-off diseases. A review. Agron. Sustain. Dev. 37(10): 1-25.

Lebeda, A. and Cohen, Y. (2011). Cucurbit downy mildew (Pseudoperonospora cubensis) biology, ecology, epidemiology, host-pathogen interaction and control. Eur. J. Plant Pathol., 129:157-192.

Lebeda, A.,Křístková, E., Sedláková, B., Kitner, M. and Widrlechner, M. P. (2019). Status 
of research, breeding and protection of cucurbits in relation to cucurbit downy mildew: their limits and perspectives. Acta Hortic., 1242.

Lehmann, M. (1991). Study on forecasting the beginning of epidemic of downy mildew (Pseudoperonospora cubensis) in field cucumbers. Pflanzenschutz-Wen, (c.f. Data Base of CAB International). 2:4-6.

Meister, R. (1999). The All-Crop, Quick Reference Insect and Disease Control Guide. Meister Publishing Co., Willoughby, OH. p. 58.

Miriam, L., Ulrike, S., Dehne, H.W. andOerke, E.C. (2004). Effects of downy mildew development on transpiration of cucumber leaves visualized by digital infra red thermography. Phytopathol., 12: 183.

Morsy, S. M., Elham, A. D. and Gehad, M. M. (2009). Effect of garlic and onion extracts or their intercropping on suppressing damping-off and powdery mildew diseases and growth characteristics of cucumber. Egypt. J. Phytopathol., 37: 35-46.

Ojiambo, P. S., Paul, P. A. and Holmes, G. J. (2010). A quantitative review of fungicide efficacy for managing downy mildew in cucurbits. Phytopathol., 100 (10): 1066-1076.

Palti, J. and Cohen, Y. (1980). Downy mildew of cucurbits (Pseudoperonospora cubensis). The fungus and its hosts, distribution, epidemiology, and control. Phytoparasitica., 8: 109-147.

Reuveni, R. and Raviv, M. (1997). Control of downy mildew in greenhouse-grown cucumbers using blue photoselective polyethylene sheets. Plant Dis., 81: 9991004.

Shankar, R., Harsha, S. and Bhandary, R. (2014). A practical guide to identification and control of cucumber diseases. Tropica seeds pvt. 1td. p. 54.

Shetty, N.V. and Wehner, T. C. (1997). Downy mildew resistance of the cucumber germplasm collection in North Carolina field tests. Crop Sci., 37: 1331- 1340.

Singh, D. and Sahore, S.K.. (2000). Integrated management of powdery mildew (Sphaerotheca fuliginea) of cucumber. Pestology., 24. 3-8.

Tsai, W. H., Tu, C. C. and Lo, C. T. (1992). Ecology and control of downy mildew of cucurbits.Plant Protec., 34: 149-161.

Utobo, E. B., Ekwu, L. G., Nwogbaga, A. C. and Wanchor, N. K. (2015). The efficacy of eco-friendly botanicals in the management of damping-off and downy mildew diseases of cucumber. Int. J. Sci. Res., 1972-1977.

Wheeler, B. E. J. (1969). An Introduction to Plant Diseases., John Wiley and Sons Limited,London, p. 301.

Yangn, X. L. I. M., Zhao, C., Zhang, Z. and Hou, Y. (2007). Early warning model for cucumber downy mildew in unheated greenhouse. New Zealand J. Agric. Res., 50: 1261-1268.

Zitikaite, I. (2002). Viruses of cucumber plants and identification of their agents. Biologija, 2: 42-46.

\section{How to cite this article:}

Daunde, A. T., R. D. Baghele and Khandare, V. S. 2020. Management of Prevalent Diseases of Cucumber (Cucumis sativus) through Integrated Approach. Int.J.Curr.Microbiol.App.Sci. 9(07): 3022-3028. doi: https://doi.org/10.20546/ijcmas.2020.907.355 